\title{
An Analysis of the Post-War Community Relations between Buddhists and Muslims in Sri Lanka: A Muslim's Perspective
}

\author{
Ahmad Sunawari Long ${ }^{1}$, Khaidzir Hj. Ismail ${ }^{2}$, Kamarudin Salleh ${ }^{3}$, Saadiah Kumin ${ }^{4}$, Halizah Omar $^{4}$ \& Ahamed \\ Sarjoon Razick ${ }^{5}$ \\ ${ }^{1}$ Department of Theology and Philosophy, The National University of Malaysia (UKM), Malaysia \\ ${ }^{2}$ School of Psychology and Human Development, The National University of Malaysia (UKM), Malaysia \\ ${ }^{3}$ Department of Theology and Philosophy, The National University of Malaysia (UKM), Malaysia \\ ${ }^{4}$ Pusat Citra, The National University of Malaysia (UKM), Malaysia \\ ${ }^{5}$ Doctoral Candidate, Department of Theology and Philosophy, The National University of Malaysia (UKM), \\ Lecturer, South Eastern University of Sri Lanka \\ Correspondence: Ahamed Sarjoon Razick, Department of Theology and Philosophy, FPI, UKM 43600, Bangi, \\ Selangor Darul Ehsan, Malaysia. Tel: 60-11-1893-1917. E-mail: sarjoonra@seu.ac.lk
}

Received: June 5, $2016 \quad$ Accepted: July 9,2016 Online Published: July 31, 2016
doi:10.5539/jpl.v9n6p42
URL: http://dx.doi.org/10.5539/jpl.v9n6p42

\begin{abstract}
Sri Lanka is a multi-ethnic, multi-religious country comprising four of the world's major religions: Buddhism, Hinduism, Islam and Christianity. Buddhists are the predominant ethnic group, constituting $70.19 \%$ of the total population, while Muslims make up the second largest minority in the country. There are many records in the history to prove well the cordial relationship between Buddhists and Muslims in Sri Lanka. However, in the past couple of years, particularly during the aftermath of the civil war, tension may be observed in the relationship between these two religious groups. This is due to a campaign undertaken by a several Buddhist nationalist groups whose intensions are to create a division among these respective societies. These groups have been carrying protests against Muslim social, cultural and religious aspects, including issuing Halal certification, slaughtering of cattle, conducting prayer services, etc. Moreover, they have disseminated misinterpretations about Muslims and Islam with derogatory speeches among the Buddhist public, for the purpose of accomplishing above division. Given the above backdrop, this paper attempts to determine the post-war relationship between Muslims and Buddhists in the country, including major interrupting factors, through analyzing Muslims' point of views. According to the results, there is no remarkable fluctuation in the relationships between Muslims and Buddhists, and Muslims have posited that there are several social, cultural and religious practices them that act as significant barriers to maintaining a better community relationship with Buddhists, such as slaughtering of cattle for meals. Therefore, almost all of the Muslims have been demanding proper guidelines regarding the slaughtering of cattle, the Niqabs (face cover of Muslim women), and other factors related to interrupting a better interaction with the Buddhists for better cordiality, within the context of Sri Lanka.
\end{abstract}

Keywords: Muslim perspective, post-war, community relationship, Buddhists, Muslims

\section{Introduction}

In Sri Lanka, a multi- religious country, members of all the communities once lived in peace and harmony with social integration with one another. Each community practised and preserved its own religious and cultural life, while sharing and respecting each other's religious and cultural values. The Sinhalese are the main ethnic group in the country, constituting three quarters of the total population. Among them, the Sinhala-Buddhists make up 70.19\% (Department of Census and Statistics, 2012), and speak Sinhala, an Indo-Aryan language. The Tamils make up the second major ethnic group, constituting $15.37 \%$ of the population. This group consists of Sri Lankan Tamils and Indian Tamils, 12.61\% of which are Hindus (Department of Census and Statistics, 2012). Tamils live predominantly in the north-eastern part of the island. The Muslims in Sri Lanka constitute only 9.7\% of the country's population (Department of Census and Statistics, 2012), and live in various parts of the country. In some regions, Muslims are more in number compared to Buddhists, and belong to three different ethno-social backgrounds: Sri Lankan Moors, Indian Moors and Malays. Others include the Memons and the Bohras (Imtiyaz, 
2012). Muslims are a multilingual ethnic and religious group, and speak Tamil, a Dravidian language.

Sri Lanka has at various times portrayed itself as maintaining inclusive ethno-religious pluralism. There has been a general climate of tolerance and co-existence, such as the case of local communities, where people of various religions and ethnicities have historically co-habited (Dewaraja, 1994). The association between Buddhists and Muslims has been tightly linked both socially and culturally since settling down in the island more than 10 centuries ago. Arab-Muslim traders and local Muslims have immensely contributed to protect and expand their reigns during the regime of Buddhist leaders (Dewaraja, 1994). During the $19^{\text {th }}$ and $20^{\text {th }}$ centuries, Muslim leaders and scholars toiled hard for Sri Lanka's independence from colonial rule (Farook, 2014). They protected the territorial integrity and sovereignty of the country, irrespective of ethnic, religious and lingual differences. Post-independence, the relationship between Buddhists and Muslims was strong, and they thus shared great mutual respect and understanding (Lebbe, 2010). The Muslim group has been identified as a peaceful one that has maintained societal and ethnic harmonious relations with its neighbours. Furthermore, Muslims have also maintained a very good relationship with Buddhist rulers. This cordial relationship with Buddhists and their rulers made the Muslim community in the country among the privileged. In fact, it is worthy to note that, compared to other minorities who have lived with majorities in other parts of the world; the Muslims in Sri Lanka have enjoyed a variety of fundamental rights, as well as socio-cultural and economic privileges.

On the other hand, during the aftermath of the Sri Lankan government's victory of war (2009) against the Liberation Tigers Tamil Elam (LTTE), a series of tense situations have been observed in terms of the relationship between the Buddhist and the Muslim communities. This tension has sparked when the Buddhist nationalist groups (BNGs) Bodu Bala Sena (BBS), Sinhala Rawaya and Rawana Balaya, have posed questions about the ethnic and religious features of the Muslim community in the country. Muslims' rights pertaining to religious obligations have been immensely questioned through provocations by respective groups. During their rallies, the most prominent hard-liner groups have used coarse, derogatory language to undermine and question Muslims and their religion, and spread misunderstanding and misperception about them among the majority Buddhist community in the country (Centre for Policy Alternatives, 2013). There have been several incidents recorded during which Muslim religious places of worship were attacked, and this has consequently imposed challenges in practicing religio-cultural identity, customs and fundamentals. In this regard, recently, Muslims have faced a number of challenges in terms of anti-Halal (permitted to eat according to Shariah) and anti-Hijab (head and face covers) agitations, as well as the destruction of places of worship, the prohibition of call to prayer using loudspeakers, intentional disruption of prayer services, animal anti-slaughtering movements, anti-Shariah agitations and so on. Furthermore, these groups have propagated and advised Buddhists to reduce or avoid socio-cultural and economic interactions, as well as relations with members of the Muslim community.

These incidents have created a tense and complex situation, as well as a feeling of marginalization among the Muslims, especially those who live in Buddhist-populated areas throughout the country. Moreover, these incidents have contributed to clashes in opinions, and misunderstandings, thus further damaging the once-healthy relationship between Buddhists and Muslims in the country. Although Muslims are regarded as having remained largely loyal to the state during the 30-year ethnic conflict and civil war, they are currently expressing fear of religious marginalization, which has increased uncertainty of their co-existence and long-term cordial relationship with other major ethno-religious groups, especially Buddhists. Given the above backdrop, this study attempts to investigate the nature of the post-war community relationship between Muslims with Buddhists, as well as the intervening factors on it, with an analysis of the perspective of Muslims. In order to achieve the above objectives of this study, a total of 11 items have been used in a questionnaire. The considered items attempt to measure the relationship between the Muslims and Buddhists, such as interests to interact with Buddhists, befriending, maintaining business links, participating in cultural events and helping them. The items also identify the barriers that exist in terms of Muslim behaviours at a social level, for longer advancement of the relationship.

\section{Literature Review}

A number of prior research works have been conducted to study the traditional relationship between the Sinhala-Buddhists and the Muslims in Sri Lanka, since historical times, onward. Extensive field work was performed by Lona Dewaraja (1994), entitled 'The Muslims of Sri Lanka - One Thousand Years of Ethnic Harmony 900-1915', the primary objective of which was to investigate the cordial relationship between Buddhists and Muslims. The author presents in this research the historical evidences for the wholesome relationship between Buddhists and Muslims that has developed over a period of one thousand years (i.e. from the time of Sri Lanka's first known contacts with the Islamic world, approximately in the eighth and ninth centuries, till the beginnings of the British rule). The results reveal a gradual evolution of a mutually beneficial relationship between migrant Muslim traders and the agricultural Sinhalese-Buddhists, from 900 to 1500 A.D. 
During this period, which laid the foundation for racial and religious amity, economically and politically, the Muslims were considered assets to the Sinhalese kings, who in turn provided protection and gave permission for merchants to settle down in the Sinhalese Kingdoms within Sri Lanka. So, the supports given by the Muslims, who suffered at the hands of the Christian powers, to the Sinhalese Kings of Kotte (1412-1597) and Sitawaka (1521-1594), especially to check the European assaults and economic recession. In addition, the author describes that the process of structural assimilation of Muslims into the Kandyan body politics differs from cultural assimilation where the migrant culture is totally submerged in the host culture, and the Muslims remained a distinct and cohesive group in the Kandyan Kingdom (1521-1817), devoutly adhering to Islam and all its cultural attributes, but were as group assimilation into the Kandyan people. This process of structural assimilation, which took place without any erosion of the cultural distinctiveness of the Muslims, is perhaps unique in minority-majority relations. She argues that, in Sri Lanka, the Muslims did not undergo a shocking experience such as in Burma, Thailand and China, and they were able to maintain a subtle balance, thus preserving an unbroken record of peaceful co-existence with their neighbours. Besides that, the researcher analyses the causes of the 1915 outbreak between Sinhala-Buddhists and Muslims, and argues that it was not a disagreement between Islam and Buddhism, but rather a reflection of the political and economic tension caused by the rapid socio-economic changes after 1815 , as well as the consequent de-stabilisation of a traditional society, disrupting its components, that for centuries had been harmoniously welded into a well-integrated system.

Assif Hussain (2013) investigates 'the unbreakable bond why Sinhalese-Muslim relations have stood the test of time' with the aim of finding the unbreakable tie between Sinhalese-Buddhists and Muslims for several thousand years through four major inter-twined factors: intermarriage, conversions, hereditary house names, and the Sinhala language. First and foremost, the Arabs freely intermarried with the daughters of the land, thus giving rise to the present-day Muslim community. Such intermarriages lasted for several centuries, and have even continued to date, with the infusion of Sinhalese-Buddhists and Arabs blood. Secondly, the Muslims had a practice to purchase children of other communities (especially from Buddhists) from their parents, who were then raised as Muslims. These children were assimilated into the Muslim community, and for this reason, it is possible that they too had contributed a significant infusion of Sinhalese blood to the Sri Lankan Muslim community through maternal and paternal lines. Thirdly, many Muslims in historical Kandyan Regions had had definite hereditary patronymics of the Vasagama type found among the Buddhists. Fourthly, most of the Muslims are bi-or tri-lingual, and speak several languages depending on their geographical location. These hereditary patronymics and language abilities coupled, with their wide disbursement throughout the island, have given them a unique interaction with the Buddhists.

As a well-known journalist, Victor Ivan (1997) describes in his famous work of [Muslim Nation and its Future], that the 'evils' prevailed in the relationship between the Buddhists and the Muslims, including the Muslims' political relations with the Buddhists in the post-independent era of Sri Lanka. Additionally, he discusses the cleavages among the Tamil-Muslim relationship, pointing out that there could never have been a better interaction among those communities since the post-independent era even the Muslims' mother language is Tamil as the Tamil community, and shared a number of cultural practices among them. He further describes that the ethnic conflict and counter violence of the Liberation Tigers Tamil Elam (LTTE), especially in the expulsion of the Muslims from the Northern Province in 1990s and the unjustified killing of the Muslims in the Eastern Province, have caused further division between Tamil and Muslim communities. On the other hand, he also describes that the Muslims have been discriminated and targeted since the 1900s by the Buddhists, such as the 1915 invasion of violent incidents against the Muslims in Sri Lanka. Even though this situation has prevailed, the Muslims have been deliberately enjoining their hands with the Buddhists, yet he points out that this is an unhealthy way the Muslims have chosen to accomplish their future objective of forming a separate territory of their own. In fact, he is a critic of the Muslim relation with the Buddhists, while emphasising the importance of maintaining cordial relations with the Tamil community, despite the mutual misunderstanding and grievances between the Tamils and Muslims.

Kumari Jayawardena (1986) describes the nature of the 1915 conflict between the Sinhala-Buddhists and Muslims, and the evolution of Sinhala-Buddhists consciousness, in the context of the last 100 years of colonial and post-colonial rule in Sri Lanka. She discusses this in her famous book "Ethnic and class conflicts in Sri Lanka", in the 3rd chapter entitled "The Anti-Muslim Agitation of the Sinhala Merchants." According to her perspective, the evolution of the Sinhala-Buddhists' consciousness had originally arisen as a base for the struggle for national independence against the British colony in the 1900s. This consciousness was at one stage directed against the colonial power, but unfortunately it also contained elements of Sinhala-Buddhist chauvinism that adversely affected other ethnic groups, particularly the coast Moors, who are traders found in urban and rural 
areas in Colombo. She also describes that the last 100 years have included many long periods of ethnic harmony during which various classes composed of many ethnicities acted together in the pursuit of their class interests, ignoring or disregarding their ethnic affiliations.

Another study was conducted by Riza Yehiya (2013) on "The asymmetric relationship of Buddhist-Muslim bond in Sri Lanka". He argues that the community relationship between Buddhists and Muslims in Sri Lanka has been tied since historical times, but some external pressures such as imperialism, colonialism, extremism, and inner politics, to some extent, succeeded in dividing it throughout history. He further discusses that the post-colonial political leadership was inspired by a Western mindset, trained and nurtured in Western colonial philosophy and morals, and had ruled the country no better than Western colonial masters. Therefore, deplorably, in the history of Sri Lanka, this religious difference was exploited by the British colonialists and their affiliates to put a block in the tested Buddhist-Muslim relationship, as a 'divide-and-conquer' strategy. Moreover, he discusses that, nowadays, a few politicians use religion as a tool to conceal their bankruptcy and draw their energy from the religious and cultural dynamism of the people to re-launch and re-brand them. According to his point of view, the post-war outburst against Islam in Sri Lanka, constituted by a segment of Buddhists, is not indigenous, but rather an alien or global stirring by a third force that wants to attack the asymmetrical power balance that buttresses Buddhism in Sri Lanka.

In 2010, Mohamed Haris carried out his doctoral thesis entitled "Buddhists' perception of Islam and Muslims in Sri Lanka: An empirical study in the context of Da'wah (Islamic call)", with the objective of finding perceptions of Buddhists on Islam. In this study, he explains that, although all of the communities were living in a peaceful and harmonious environment, the peaceful co-existence was targeted by some external and internal powers, such as the 'divide-and-rule' policy of the British colonial government, and Sinhala-Buddhist nationalism. A small segment of each community became communal-minded, and perceived others with suspicion; even the Muslim community is no exception with regards to this phenomenon. He also describes that the emergence of ethnicallyand religiously-based political parties played a major role in shaping the trustworthiness of each community towards others in the country. In addition, analysis and results of this field study show that the majority of the Buddhists still have a favourable opinion on the Muslims of Sri Lanka, and they are interested to interact with the Muslims. It is noteworthy that $73 \%$ of them had an interest to learn Islam. However, a small group of Sinhalese, especially intellectuals, had negative perceptions on Islam. The slaughtering of cattle which undertaken by the Muslims in the country as a whole, the manner the Muslims demanded their rights, the exclusive form of Islam among the Sri Lankan Muslims, the way spread Islam in the country, the rights of Muslim women in public places are some key issues on which Buddhists have negative opinions. The reason for the negative perceptions are numerous, including the ill-treatment and un-Islamic behaviour of some Muslim business men who came from South India (Coast Moors), opportunistic politics of Muslims, the un-Islamic lifestyle of some Muslims, misunderstandings and misinterpretation of Islam, a religiously-based political party and its approaches and demands, Muslim attitude and mentality towards non-Muslims; are some key facts seen from the Muslim side. The lack of interaction, communication gaps, extreme thought of some Sinhalese-Buddhists intellectuals such as Anagarika Dharmapala (1864-1933), politicised Buddhism, and Sinhala-Buddhist nationalist ideologies, are some obstacles to mutual understanding and respect. The important findings according to the survey were that religion was not the main factor behind the conflict between Muslims and Sinhala-Buddhists in Sri Lanka.

In the past couple of years, numerous studies have been conducted on the relationship between the Sinhala-Buddhists and the Muslims of Sri Lanka, from the maritime period, to date. The history of Sri Lanka provides abundant proof of a peaceful cohabitation between Buddhist and Muslim communities, regardless of all their religious and cultural differences. Political and trade relationships were also abundant. Both communities have shown collaboration and cohabitation in a commendable manner. However, in 1915, there was a dispute in the relationship between these two communities. In fact, this invasion was not against the Muslim community as a whole, but rather targeted South Indian traders (Coast Moors), because of server revelry in trading in the Metropolitan areas of Sri Lanka. With this exception, there are no records in history of any rupture between these two communities, until the end of the war (2009), which was held between the Sri Lankan government forces and the Liberation Tamil Tigers Elam (LTTE) in Sri Lanka. However, in the post-war context of Sri Lanka, a series of tense situations have been observable between the Buddhist and Muslim communities. Therefore, this study attempts to investigate the nature of the post-war community relationship between the respective societies, with analysing the major barriers to maintain a better relationship between them, through an academic investigation that involves a questionnaire survey. 


\section{Material and Method}

A questionnaire survey was conducted in order to measure the relationship between the Buddhists and the Muslims during the aftermath of the recent tensions that took place in Sri Lanka. The survey includes the Muslims, who reside in 14 major districts of Sri Lanka, namely, Colombo, Gampaha, Kandy, Matale, Kalutara, Matara, Anuradapura, Polonnaruwa, Ratnapura, Kegalle, Puttalam, Kurunegala, Badulla, and Moneragala. The selection of these districts is because these districts are where both the Buddhist majority and the Muslim minority live very densely together, side-by-side. The survey participants are the general public, as a non-probability, convenience-based sampling technique in the respective districts. The participants have been selected based on the percentage of the population in each district from the total population of Sri Lanka. In order to measure the relationship, about 384self-administeredquestionnaires were distributed among the participants in the 14 districts, and 312 questionnaires were received. The questions were organized into two parts. Part one comprises 11 questions, while part two comprises six demographic details of the respondents. The data was analysed using the Statistical Package for Social Science (SPSS) software. Under this segment, the findings of the study on the post-war relationship between Buddhists and Muslims in Sri Lanka are presented in detailed. To measure the abovementioned findings, simple frequencies and percentages, and the mean, were calculated. The discussion and interpretation would is based on the 11 items of measurement in the questionnaire, as this is a descriptive research.

Analysis of Respondents' Demography: The questionnaire provided information regarding social and demographic variables such as gender, academic level, age, occupation, marital status and residing districts. For the purpose of the study, education level was categorized into five categories: none educated $(5 \%)$, primary $(17 \%)$, secondary $(48 \%)$, vocational $(10 \%)$, and University $(20 \%)$. Age was categorized into six categories: 20 years old and below (4\%), 21 to $30(12 \%), 31$ to $40(25 \%), 41$ to $50(30 \%), 51$ to $64(25 \%)$ and 65 years old and above (4\%). Occupation comprised unemployed (10\%), student (15\%), self-employed (46\%), governmental sector (15\%), and private sector (14\%). Meanwhile, marital status comprised bachelor (42.4\%), married (56.1\%), and divorced (1.4\%). Lastly, gender consisted of female (68.6\%) and male (31.4\%).

\section{Results and Discussion}

Community relationship with the Buddhists: Muslims' Point of View: Since the main objective of this study is to determine the nature of post-war community relationship between Buddhists and Muslims, and the barriers to maintain a better interaction, this topic refers to the level of interest by the Muslims to intertwine with the Buddhists in the community during the current context of Sri Lanka. Thus, this topic includes the frequency of their participation. This is measured by considering how active the respondents are in social interaction with Buddhists, participation in their cultural events, interest of befriending them, helping them and maintaining business deals. Also, this study analyses Muslim-based issues related to maintaining a better relationship between them, such as the slaughtering of cattle, Hijab (headscarf) and Nikab (face cover), and issues regarding Mosques and places of worship. Therefore, a total 11 major items were constructed in accomplishing the mentioned objective of distributing the questionnaire among the Muslims.

\section{Item: 1 - Level of interest to interact with Buddhists}

This item involved investigating the extent the respondents are interested to interact with their fellow Buddhists during the aftermath of the post-war context of Sri Lanka. Therefore, according to the results (Appendix I: Table 1), this element has yielded an affirmative response from $76.9 \%$ of the respondents; they are still interested to interact with the Buddhists with maintaining a cordial tightness, while only about $7.7 \%$ of the respondents did not express their interest in interacting with their fellow Buddhists. The mean value (1.8397) tends to move to the agreement between the respondents. The mode of 1.0000 which is highest frequent score and the standard deviation (.95221) strongly support this finding as well. In addition, the Muslims, since settling down in Sri Lanka 1200 years ago, had established a very strong cordiality with the Buddhists, and they integrated well and shared prosperity and adversity (Dewaraja, 1994). James Cordiner (1807) points out that "The Sinhalese (Buddhists) who profess the religion of Mohammad (Islam) appear to be a mixed race." In the period mentioned, the Buddhists and the Muslims intertwined as a mixed race that cannot be identifiable to belong to a certain community in Sri Lanka. Also, the Muslims attempted in various ways to integrate their offspring with Buddhists in modern and contemporary Sri Lanka. For instance, there is a tendency among Muslims parents to educate their children in the Sinhala language (Buddhists language), with the purpose of integrating them with the Buddhist society (Herath and Rambukwella, 2015). Though the Muslims in Sri Lanka are already integrated with the Buddhist society in myriads of ways, the BNGs have the potential to unsettle this integration (Ibid). However, the result of this field survey has proved that the Muslims show keen interest to strengthen their interaction with 
Buddhists, and thus preserve it, even they were attacked by a segment of Buddhists in the past few years.

\section{Item: $\mathbf{2}$ - Level of interest to participate in cultural events}

The item involved investigating the extent the respondents are interested to participate in Buddhist cultural events in Sri Lanka, such as wedding ceremonies or funerals. Based on the result (Appendix I: Table 2), more than $1 / 3$ of the respondents (37.8\%) have agreed that they are still participating at Buddhist cultural events, while about $39.1 \%$ of them expressed that they do not participate in these events. Furthermore, approximately a quarter of them point out that they are not aware of these events. In addition, the mean value strongly tends to move to the point of 'undecided', but the highest frequent score (4.0000) reveals the disagreement of the respondents. Therefore, it could be seen here that most Muslims are not interested in participating in Buddhist cultural events. This is because the Muslims are well-bonded with their religion (Herath \& Rambukwella, 2015), and generally they thus have a sense of fear that some time they would have to pass the boundary of Shariah when interacting with Buddhists during these events, for instance, Islam prohibits Muslims participating in events which include alcohol consumption (Qadri,1986). However, there are records in history that the Muslims in most of the areas in Sri Lanka have participated in social and cultural events by Buddhists, such as wedding ceremonies and funerals (Hussein, 2009). The Muslims have taken part in events such as "Awrudhu Uthsawa" (Carnivals held following festival days of Buddhists) and "Dewalaya" (A Buddhist religious event), not for worship, but rather to show respect for Buddhist cultural events. So, according to this survey, around $40 \%$ of the Muslims in Sri Lanka participated at the cultural events with the purpose of interacting with the Buddhists in their social lives and cultural events.

\section{Item: 3 - Interest in befriending}

The item attempts to investigate the respondents' befriending status with the Buddhists in Sri Lanka. Befriending here refers to an in-depth relationship, combining trust, support, communication, understanding, empathy and intimacy, and is a relaxed relationship (David B. Annis, 1987). In fact, it can be observable in most of the areas of Sir Lanka that Buddhists and Muslims, especially, youngsters and elders, maintain a wonderful friendship at a personal level, even in the present. Therefore, according to the result (Appendix I: Table 3), about $67.3 \%$ of the Muslim respondents have genuine interest in befriending Buddhists, while only about $28.8 \%$ of them did not show such an interest. Therefore, about $54.5 \%$ of the Muslims have Buddhist friends in Sri Lanka. The mean value remains at the point of agreement (2.0705), and the mode value reflects 1.0000 as the highest frequency score, which is strong agreement by the respondents in this variable. These intentions have also been seen in the history held among the Buddhists and Muslims, which shows their friendship in the Kandyan Kingdom in Sri Lanka, that during the $17^{\text {th }}$ century, under the King Aurangzep the victorious Moghul armies had penetrated into South India, and subsequently rumours were spread that soon Sri Lanka would be engulfed in the mighty Moghul empire. But, at that time the Muslims in the island (Sri Lanka) were waiting to join hands with the Buddhists with the purpose of protecting the nation from the Moghul Muslim empire, even though they had realized the benefits from a Muslim country if it was engulfed by the Moghul (Dewaraja, 1994). Also, a Muslim businessman from Galle mentioned that:

"I studied in the Sinhala medium, we still have that connection. If something were to happen to me, the first person to come to help is a Sinhalese (Buddhist) classmate. A good example was the 2004 tsunami. Water came up to this level (indicate as wall with his hand) and everything was a mess. We had no hope. That time the first person to call me a Sinhalese person. He came to my place to see me with some ration items." (Second hand interview from Herath and Rambukwella, 2015).

So here this Muslim has expressed his great happiness with his widespread friendship network with Buddhists. Therefore, the Muslims have always attempted to maintain friendship with Buddhists. Even a segment of Buddhists attempted to isolate Muslims from them, and according to the field survey, this is the current nature of the Muslims.

\section{Item: 4 - Interest in helping}

This item requested the respondents to verify whether or not they are interested to help Buddhists in the post-tension context of Sri Lanka during their social lives. According to the result (Appendix I: Table 4), this item yields an affirmative response from $91 \%$ of the respondents, who show that they are interested in helping Buddhists, while only $6.4 \%$ of the Muslims were not interested to help them. Also, the mean value tends to move to the point of agreement, and the mode value (1.0000) reflects the highest frequency score in this variable. The value of standard deviation, which is scattered closely to the mean, also shows strong support for this result. In addition, during the period of 900-1500 A.D., which saw the foundation of racial and religious amity in Sri 
Lanka, the Muslims were economic and political assets to the Sinhala-Buddhist monarchs (Dewaraja, 1994). Also, during the same period, Muslim military advisors presented from Muslim countries and advised the Sinhalese-Buddhist rulers against the Portuguese, Dutch and British conquests, and had participated in battles against them in Sri Lanka (Yehiya, 2013). Therefore, this is how the Muslims helped the Buddhists throughout the Kandyan Kingdom, and this same nature is observable in current Sri Lanka. The field survey concluded that almost all of the Muslims were interested in helping their fellow Buddhists, even though the Muslims were attacked by a segment of the Buddhists recently.

\section{Item: 5 - Business connections}

The item requested the respondents to verify whether or not they maintained business dealings with Buddhists, within their residential towns and outstations in the post-tension context of Sri Lanka. The result (Appendix I: Table 5) reveals substantial business links among Buddhists and Muslims in Sri Lanka. About 55.8\% of the Muslim respondents agree with the statement that they do maintain respective deals in the post-war context, just as they did during pre-tension times, without any interruptions, while around $40 \%$ of them express disagreement. Although the mean value strongly moves to the point of "undecided", the mode (2.0000), which is the highest frequency score, remains at the point of agreement. Besides that, as mentioned elsewhere, in some places of Sri Lanka, commercial interests have played a substantial role in anti-Muslim campaigns (Farook, 2014). However, in areas in the Southern Province, such as Galle, the business community, which constitutes Buddhists and Muslims, has successfully resisted external attempts in rousing religious divisions. There remains an overarching unity among them that has helped to resist religious division (Herath \& Rambukwella, 2015). Moreover, in these areas, the Buddhist and Muslim businesses, as well as the civil society, have cooperated to take pre-emptive action against religious violence (Ibid). This unity is in line with the overall result, and this shows that there remains good tightness among the Buddhists and the Muslims in terms of business links. Also, the Muslims did not anticipate any threats during the aftermath of the recent campaigns from the BNGs. It is worthy to mention here that there is evidence in the history that in Kandyan times (1469-1815), there existed a healthy and friendly tie between Buddhists and Muslims, even in terms of business connections (Dewaraja, 1994).

\section{Item: 6 - Observing complexities in the relationship}

The item requested the respondents to verify whether or not they observed complexities in their relationships with the Buddhists during the aftermath of the campaigns carried out by the BNGs. The result (Appendix I: Table 6) shows that about $75.6 \%$ of the respondents express the opinion "strongly disagree" and "disagree" with this statement. The mean of this variable (4.2500) slightly tends to move to the point of strong disagreement, and the mode reflects the highest frequency score of 5.0000 . However, only approximately $18 \%$ of the respondents believe that there could be seen remarkable issues in the relationships between these two communities following the recent campaigns. The Buddhists have had serious clashes with the Sri Lanka Thawheed Jamaaath (SLTJ), who the Buddhists refer to as "newer sect Muslim youngsters", and feel that they are an internationally connected group, unlike the "traditional" Muslims, who are mainstream Muslims among the society (Herath \& Rambukwella, 2015). Also, the Muslims believe that a cordial relationship characterized by the interaction between Buddhists and Muslims for generations would not be replicated in the younger generation if BNGs continue to pose a threat (Ibid). According to this survey, most of the Muslims confirmed that they did not observe substantial complexities, even in the aftermath of the BNGs attacks against them; on the contrary, they expressed their confidentiality that external powers cannot intervene on the cordiality which has been maintained for over 10 centuries.

\section{Item: 7 - Social and cultural practices which interrupt community relationship}

This item attempts to verify the agreement by respondents on the set of religious and cultural practices which interrupt the community relationship with Buddhists in Sri Lanka, such as conducting butcher shops, slaughtering of cattle during the Hajj festive season, Muslim students failing to kneel down to Buddhist teachers in Sinhala (Buddhist) schools, etc. According to the result (Appendix I: Table 7), about 33\% of the Muslims believe that there have been a few notable cultural and religious limitations in relation to maintaining interaction with non-Muslims, especially with the Buddhists within the context of Sri Lanka. The Buddhists, especially those from the Western and Southern provinces, feel that since the immemorial time Muslim women wore sarees (a garment consisting of a length of cotton or silk elaborately draped around the body), just like the Buddhist and Tamil women, albeit in a different style, and would cover part of the head with the saree itself. However, currently, many Muslim women wear the Hijabs, and a small minority wear the Niqabs (Herath \& Rambukwella, 2015). Also the recent rhetoric by the BNGs has pushed the Buddhists to change in Muslim attire as an exclusivist trend (Rifai, 2013). So nowadays, the Buddhists have considered that Muslims have become 
exclusivists, since they try to be culturally distinct from others, and have maintained a different attitude in interacting with other ethnic groups (Herath \& Rambukwella, 2015). Therefore, this view by the Buddhists toward the Muslims can become a disruption to maintain a better interaction with the Muslims in the complex post-war situation in Sri Lanka. Besides that, approximately half (48.1\%) of the Muslims express that they could not agree with statement in Item 7, which means that they do not view any religious or cultural practices that prevailed among them as disruptive factors to the community relationship with the Buddhists. Among them, about $12.2 \%$ express an affirmative disagreement. It is noteworthy, in a previous research $55.3 \%$ of the Buddhist respondents have expressed that they did not think there have been social or cultural barriers in advancing the relationship with the Muslims (Razick et al., 2016). Hence, according to these respondents' point of views, those practices cannot be counted as barriers by the Buddhists. This can be addressed in an attempt to understand the nature of Muslims' religious and cultural practices.

\section{Item: 8 - Essentiality of guidelines on the slaughtering and trading of cattle}

The item requested the respondents to express their opinions in the essentiality of proper guidelines to the slaughtering and trading of cattle within the context of Sri Lanka. In fact, this is not a directly connected variable to measure the community relationships between the Buddhists and the Muslims, but rather an indicator that has been seen as a basic element in order to maintain and preserve the relationship between them. Since the post-war period (2009) onward, BNGs have been intensely protesting against butcher shops and the trading of bulls undertaken by the Muslims in Sri Lanka, declaring them as an anti-Buddhism activity. Therefore, in the current context of Sri Lanka, the Buddhists have instigated against the Muslims in expanding cattle trading and slaughtering. Thus, with this item, the respondents were requested to verify whether they have agreed that the Sri Lankan Muslims required proper guidelines in the slaughtering and trading of cattle, which is suitable with the current context of Sri Lanka in order to maintain and preserve the relationship with the Buddhists, with avoiding undue allegations upon them. According to the results (Appendix I: Table 8), almost all 87.2\% of the Muslims strongly demand proper guidelines in the slaughtering and trading of bulls and cows according to Shariah limitations, and included government policies which matched with the context of Sri Lanka. The result was further confirmed with the mode value (1.0000), which reflects a strong agreement by the respondents as the highest frequency score, and with a mean value (1.4038) which tends to move to the point of 'agreement'. Besides that, in another study, Buddhist respondents were requested to verify whether the slaughtering of cattle is a remarkable barrier in maintaining better interaction with the Muslims, in the context that the slaughtering of cattle is an anti-Buddhism activity. Almost $80 \%$ of the Buddhists expressed that this was a strong barrier to carry the relationships (Razick et.al. 2016) and alternatively, they suggested to import the beef from foreign countries instead of killing cattle in this country (Jones, 2015). Consequently, in order to respond to the above position of the Buddhists, Muslims expressed here their desire in demanding proper guidance in the slaughtering and trading of cattle, especially bulls and cows, by religious experts and government officials, in terms of environmental compatibility of Sri Lanka. Therefore, in the case of Muslims, this could be seen as a wonderful response to the Buddhists, particularly to maintain a better relationship with them, and to decrease their misunderstanding regarding this aspect. Also, with this result it could be understandable that the Muslims have intensely attempted to protect the community relationship with Buddhists, and addressing any negative factors interrupting this relation. Therefore, the aforementioned view by the Muslims will surely encourage the Buddhists to carry a better relationship with the Muslims in Sri Lanka. Based on the results, the majority of the Muslims are under this opinion.

\section{Item: 9 - Requiring guidelines on Hijab (headscarf) and Niqab (face cover)}

In current Sri Lanka, most of the Muslim women wear the Hijabs (headscarves), while a small number wear the Niqabs (full-face cover). There are a series allegations and criticisms on the Niqab of Muslim woman, and to some extent, on the Hijab, from various parties of Buddhists, especially the BNGs. Samaranayaka (2013) points out that the Muslims must understand the implications of Burqas or Niqabs on themselves, because wearing of these articles make them more conspicuous in a crowd, inviting undue attention from troublemakers. Also, the practice of wearing the Niqab has been identified by other communities in Sri Lanka as a gendered trope through which are perceived as fundamentalist trends in Muslim societies (Herath \& Rambukwella, 2015). In addition, the BNGs have attempted to ban the Hijab and Niqab of Muslim women within Sri Lanka, and they have disseminated faulty opinions about Muslim women's Niqab with a derogatory name ("Goni Billa-sack", or "wrapped devil"). The Muslim woman's Niqab has been called the mentioned name, because the Buddhists used to express that their kids were afraid when they see Muslim women wearing this Niqab dress. It is noteworthy to mention here that nowadays the Muslims in Sri Lanka are confused on whether the Niqab is obligatory or optional in Shariah. However, this is not an issue, but the Muslims must concentrate on how to avoid the 
inconveniences caused with their Niqabs to others, especially to the Buddhists. Also, the Muslims should think about how to dissolve or remove the allegations towards the Muslims with the name of Niqab. Thus, Item 9 attempts to investigate the respondents' desires on the essentiality of Sharia guidelines on Hijabs and Nikabs to the Muslim community, in order for avoiding inconveniences caused toward non-Muslims. According to the result (Appendix I: Table 9), about 35\% of the Muslim respondents rejected this statement, as they do not feel the essentiality of Shariah guidelines on the attire of Muslim woman. Therefore, according to their point of view, there has already been a proper system among Muslims on wearing Hijab and Niqab, which is currently followed by the Muslims in Sri Lanka. However, approximately $60 \%$ of the Muslims express their demand toward the guidelines on Hijab and Niqab, especially how to maintain attire as not to negatively affect others, particularly the Buddhists. Specifically, this opinion has been expressed by the aforementioned percentage of the Muslims, since it might have a good intention of maintaining a better relationship with the Buddhists, and not negatively affect them. Therefore, based on the result, the Muslims always attempt to compromise the controversial characteristics with the Buddhists. Therefore, the religious leaders and scholars together have to make an effort to fulfill their demand and direct them with perfect Shariah guidelines which would be adaptable to the current context of Sri Lanka for maintaining a better interaction with the Buddhists.

\section{Item: 10 - Desire of compromising mosque and worship related issues}

As mentioned earlier, Muslim places of worship were attacked, and prayer services were interrupted in a number of mosques. In some mosques, prayer services were paralyzed because of the fearful situation created by the BNGs during their campaigns in recent years. The mosques were disgraced with derogatory statements such as "mosques are the centre of nurturing terrorism in Sri Lanka". God's name was written on the interior walls of the mosques in pig's blood (Farook, 2014). Thus, Item 10 attempts to investigate Muslim respondents about the possibility of compromising a number of aspects related to Muslim behaviours and places of worship that affect the routines of the Buddhists. There is an allegation to the Muslims that they practice their religion the way they want, despite the inconvenience caused to others living in a particular area (Samaranayaka, 2013). In fact, the purpose of this item is to investigate the desire of Muslims to compromise the inconveniences experienced by Buddhists, arisen by the existence of mosques and their functions. In fact, according to the survey (Appendix I: Table 10), around $50 \%$ of the Muslims have looked into the statement positively, and express their desire in compromising the inconveniences experienced by non-Muslims within the limitations of Shariah, such as calling for prayer with loudspeakers, and using loudspeakers for Midnight prayers (Tharaweeh) during the month of Ramadan. However, remaining half of the Muslims argue that the mosque related aspects could not be compromised. These respondents have intended to follow Islam strictly, and are not ready to surrender their religion to please BNGs (Imtiyaz \& Saleem, 2015). This expression might be because of the aggressive interests of the Muslims to strictly follow their religion. In fact, these interests, along with the growing exclusive form of Islam in the majority of Buddhist areas, as well as their mosque building activities, are key contributing factors to the recent campaigns against them in the current context of Sri Lanka (Imtiyaz \& Saleem, 2015).

\section{Item: 11 - Desire of establishing Shariah guidelines}

There are various issues in Shariah regarding Muslims interacting with Buddhists. For instance, a Muslim student kneeling down to a Buddhist teacher, or a Buddhist student kneeling down to a Muslim teacher, in schools, showing a Muslim's dead body to a Buddhist woman, a Muslim setting fire to the lamp in Buddhists' events, and so on. All of these practices according to Shariah are prohibited, but at the same time these practices are the Buddhists' habits and are permitted according to Buddhist philosophy. The Muslims in Sri Lanka usually face these problems when interacting with Buddhists. This situation makes the Buddhists misunderstand Muslims most of the time. Thus, Item 11attempts to investigate whether or not it is essential to establish Shariah guidelines which possibly match and are flexible to the setting of Sri Lanka, in order for maintaining a better relationship with the Buddhists. Based on the survey result (Appendix I: Table 11), approximately $50 \%$ of the Muslims express their desire to initiate the above guidelines in order to maintain a better interaction with Buddhists, which would included a minimum of allowable limitations in terms of Muslim and non-Muslim relations, specifically as matched by the current context of Sri Lanka. This decision is further supported with a mode of 1.0000 , which is the highest frequency score in this variable. Meanwhile, around $40 \%$ of the respondents did not prefer initiating new Shariah guidelines related to maintaining a better relationship with non-Muslims. Therefore, here the religious leaders and scholars have the responsibility to direct the Muslims toward the correct path, especially in terms of maintaining relations with non-Muslims, through offering them perfect and flexible Shariah guidelines that are adaptable to the current context of Sri Lanka, to avoid unnecessary issues usually arisen by the relationship with the Buddhists. 


\section{Conclusion}

As a conclusion, in this study, a total of 11 items were used to examine the nature of the Muslim relationship with the Buddhists during the aftermath of the intense campaigns in the past couple of years in Sri Lanka. In fact, this study has attempted to determine two main areas. Firstly, the Muslim relationship with the Buddhists, using Items 1- 6. Secondly, major barriers, using Items $7-11$. According to the results, the Muslims interact well with the Buddhists since immemorial times to date, even during the aftermath of the recent campaigns against them. A sizable number of Muslims befriended Buddhists in their social lives, and are interested in helping them. Also, more than $50 \%$ of the Muslims have business connections with Buddhists. However, most of the Muslims did not show interest in participating in Buddhists' cultural events. This might be because of their religious resistance in relation to participating in other religious or cultural events, which would break Shariah compliance. Therefore, the Muslims are strongly firm that there are no remarkable issues in the relationship with the Buddhists, even after the BNGs carried out the campaigns against them. Moreover, a sizable number of Muslims have accepted that there would be a particular set of cultural or religious barriers to the Buddhists in maintaining a relationship with the Muslims. But they have justified it with expressing that this depends on the Shariah guidelines, and the Muslims cannot exceed this boundary. Also, the Muslims have strongly demanded proper guidelines in relation to the trading and slaughtering of cattle, Muslim women's attire, and guidelines in maintaining a smooth relationship with the Buddhists. Furthermore, the Muslims have expressed their desire to reach a compromise with the Buddhists regarding inconveniences arisen through the mosque activities and prayer services. Therefore, efforts to attack the Muslims' social, cultural and religious aspects are unjustifiable. Also, attempting to damage the positive stereotype of the Muslims among Buddhists is blameworthy as well. As a final point, here the issue of the Buddhist-Muslim relationships is connected to the overall issue of majority-minority relations. So the researcher believes that it is possible to find some other important facts regarding this relationship through carrying out further academic investigations in this field.

\section{References}

Badone Jones, R. N. (2015). Sinhala Buddhist Nationalism and Islamophobia in Contemporary Sri Lanka. Honors Theses, The Faculty of the Department of Anthropology, Bates College.

Centre for Policy Alternatives Sri Lanka. (2013). Attacks on Places of Religious Worship in Post-War Sri Lanka. Centre for Policy Alternatives (Guarantee) Ltd. (CPA), Colombo, Sri Lanka, pp.50-51.

Cushner,K.,\& Richard Brislin, W. (Eds.). (1997). Improving inter-cultural interactions: modules for cross-cultural training programs (Vol. 2). Sage Publications Inc., Thousand Oaks.

David, B. A. (1987). The meaning, value, and duties of friendship. American Philosophical Quarterly, 24(4), 349-356.

Department of Census and Statistics-Sri Lanka. (2012). Statistical Abstract of the Democratic Socialist Republic of Sri Lanka. Department of Census and Statistics-Sri Lanka, Colombo, Sri Lanka. Retrieved fromhttp://www.statistics.gov.lk/PopHouSat/CPH2012Visualization/htdocs/index.php?usecase=indicator\&a ction $=\mathrm{DSMap} \&$ indId $=10 \&$ district $=$ Moneragala\&Legend $=3 \#$

Dewaraja, L. (1994). The Muslims of Sri Lanka One Thousand Years of Ethnic Harmony 900-1915. Colombo: The Lanka Islamic Foundation.

Engku Alwi, E.A., \& Mohd Rashid, Z.B. (2011). Cross Religious and Social Interaction: A Case Study of Muslims and Buddhists in Kampung Tendong, Pasir Mas, Kelantan.Asian Social Science, 7(8), 112-128. http://dx.doi.org/10.5539/ass.v7n8p112

Farook, L. (2014). Muslims of Sri Lanka Under Siege. Colombo: Latheef Farook.

Hussein, A. (2009). ZEYLANICA - A Study of the Peoples and Languages of Sri Lanka. Pannipitiya. Neptune Publications (Pvt.) Ltd, Colombo, Sri Lanka, pp.272-333.

Imtiyaz, A.R.M., \& Saleem, A.M. (2015). Muslims in post-war Sri Lanka: understanding Sinhala-Buddhist $\begin{array}{lllll}\text { mobilization against them. Asian } & \text { Ethnicity, } & \text { 16(2), }\end{array}$ http://dx.doi.org/10.1080/14631369.2015.1003691.

Jary, D., \& Julia J. (1991). The Harper Collins dictionary of sociology. New York: Harper Collins Publishers.

Lebbe, L.M.H. (2010). Buddhists' perceptions of Islam and Muslims in Sri Lanka: An empirical study in the context of Da'wah. Unpublished PhD Thesis. Malaysia: International Islamic University Malaysia.

Qadri, A. A. (1986). Islamic Jurisprudence in the Modern World. New Delhi, Taj Printers. 
Razick, A.S., Long, A.S., Ismail, K. Hj., \& Salleh, K. (2016). Post-Tension Relationship between Buddhists and Muslims in Sri Lanka. Research on Humanities and Social Sciences, 6(3), 107-117.

Tilak Samaranayaka. (2013, May 5). Understanding the Causes of the Sinhala-Muslim Conflict in Sri Lanka. Colombo Telegraph.

Retrieved from https://www.colombotelegraph.com/index.php/understanding-the-causes-of-the-sinhala-muslim-conflict-insri-lanka/

\section{Appendix A}

Table A1.Level of interest to interact with Buddhists

\begin{tabular}{lccccc}
\hline & Frequency & Percent & Mean & Mode & Standard Deviation \\
\hline Strongly Agree & 146 & 46.8 & 1.8397 & 1.0000 & .95221 \\
Agree & 94 & 30.1 & & & \\
Neutral & 48 & 15.4 & & & \\
Disagree & 24 & 7.7 & & & \\
Total & 312 & 100.0 & & & \\
\hline
\end{tabular}

Table A2.Level of interest to participate in cultural events

\begin{tabular}{lrrrrc}
\hline & Frequency & Percent & Mean & Mode & Standard Deviation \\
\hline Strongly Agree & 74 & 23.7 & 2.8077 & 4.0000 & 1.24294 \\
Agree & 44 & 14.1 & & & \\
Neutral & 72 & 23.1 & & & \\
Disagree & 112 & 35.9 & & & \\
Strongly Disagree & 10 & 3.2 & & & \\
Total & 312 & 100.0 & & & \\
\hline
\end{tabular}

Table A3. Interest in befriending

\begin{tabular}{lccccc}
\hline & Frequency & Percent & Mean & Mode & Standard Deviation \\
\hline Strongly Agree & 170 & 54.5 & 2.0705 & 1.0000 & 1.31825 \\
Agree & 40 & 12.8 & & & \\
Neutral & 12 & 3.8 & & & \\
Disagree & 90 & 28.8 & & & \\
Total & 312 & 100.0 & & & \\
\hline
\end{tabular}

Table A4. Interest in helping

\begin{tabular}{lccccc}
\hline & Frequency & Percent & Mean & Mode & Standard Deviation \\
\hline Strongly Agree & 176 & 56.4 & 1.5897 & 1.0000 & .82464 \\
Agree & 108 & 34.6 & & & \\
Neutral & 8 & 2.6 & & & \\
Disagree & 20 & 6.4 & & & \\
Total & 312 & 100.0 & & & \\
\hline
\end{tabular}


Table A5. Business connections

\begin{tabular}{lccccc}
\hline & Frequency & Percent & Mean & Mode & Standard Deviation \\
\hline Strongly Agree & 14 & 4.5 & 2.8077 & 2.0000 & 1.05242 \\
Agree & 160 & 51.3 & & & \\
Neutral & 16 & 5.1 & & & \\
Disagree & 116 & 37.2 & & & \\
Strongly Disagree & 6 & 1.9 & & & \\
Total & 312 & 100.0 & & & \\
\hline
\end{tabular}

Table A6. Observing complexities in the relationship

\begin{tabular}{lccccc}
\hline & Frequency & Percent & Mean & Mode & Standard Deviation \\
\hline Strongly Agree & 2 & .6 & 4.2500 & 5.0000 & 1.19820 \\
Agree & 54 & 17.3 & & & \\
Neutral & 20 & 6.4 & & & \\
Disagree & 24 & 7.7 & & & \\
Strongly Disagree & 212 & 67.9 & & & \\
Total & 312 & 100.0 & & & \\
\hline
\end{tabular}

Table A7. Social and cultural practices which interrupt community relationship

\begin{tabular}{lccccc}
\hline & Frequency & Percent & Mean & Mode & Standard Deviation \\
\hline Strongly Agree & 96 & 30.8 & 3.0897 & 4.0000 & 1.48896 \\
Agree & 6 & 1.9 & & & \\
Neutral & 22 & 7.1 & & & \\
Disagree & 150 & 48.1 & & & \\
Strongly Disagree & 38 & 12.2 & & & \\
Total & 312 & 100.0 & & & \\
\hline
\end{tabular}

Table A8. Essentiality of guidelines on the slaughtering and trading of cattle

\begin{tabular}{lccccc}
\hline & Frequency & Percent & Mean & Mode & Standard Deviation \\
\hline Strongly Agree & 262 & 84.0 & 1.4038 & 1.0000 & .99374 \\
Agree & 10 & 3.2 & & & \\
Neutral & 8 & 2.6 & & & \\
Disagree & 28 & 9.0 & & & \\
Strongly Disagree & 4 & 1.3 & & & \\
Total & 312 & 100.0 & & & \\
\hline
\end{tabular}


Table A9. Requiring guidelines on Hijab (headscarf) and Niqab (face cover)

\begin{tabular}{lccccc}
\hline & Frequency & Percent & Mean & Mode & Standard Deviation \\
\hline Strongly Agree & 178 & 57.1 & 2.2308 & 1.0000 & 1.48669 \\
Agree & 6 & 1.9 & & & \\
Neutral & 22 & 7.1 & & & \\
Disagree & 90 & 28.8 & & & \\
Strongly Disagree & 16 & 5.1 & & & \\
Total & 312 & 100.0 & & & \\
\hline
\end{tabular}

Table A10. Desire of compromising mosque and worship related issues

\begin{tabular}{lrrrrc}
\hline & Frequency & Percent & Mean & Mode & Standard Deviation \\
\hline Strongly Agree & 132 & 42.3 & 2.6731 & 1.0000 & 1.50951 \\
Agree & 6 & 1.9 & & & \\
Neutral & 26 & 8.3 & & & \\
Disagree & 128 & 41.0 & & & \\
Strongly Disagree & 20 & 6.4 & & & \\
Total & 312 & 100.0 & & & \\
\hline
\end{tabular}

Table A11. Desire of establishing Shariah guidelines

\begin{tabular}{lrrccc}
\hline & Frequency & Percent & Mean & Mode & Standard Deviation \\
\hline Strongly Agree & 148 & 47.4 & 2.4936 & 1.0000 & 1.50240 \\
Agree & 6 & 1.9 & & & \\
Neutral & 34 & 10.9 & & & \\
Disagree & 104 & 33.3 & & & \\
Strongly Disagree & 20 & 6.4 & & & \\
Total & 312 & 100.0 & & & \\
\hline
\end{tabular}

\section{Copyrights}

Copyright for this article is retained by the author(s), with first publication rights granted to the journal.

This is an open-access article distributed under the terms and conditions of the Creative Commons Attribution license (http://creativecommons.org/licenses/by/4.0/). 